\title{
Incorporation of endogenous urea nitrogen into amino acids of milk in goats fed diets with various protein levels
}

\author{
J.P. Michalski ${ }^{1,3}$, M. Czauderna ${ }^{1}$, W. Litwinn ${ }^{1}$, N. Puzio ${ }^{2}$ and J. Kowalczyk ${ }^{1}$ \\ ${ }^{1}$ The Kielanowski Institute of Animal Physiology and Nutrition, Polish Academy of Sciences, 05-110 Jabłonna, Poland \\ ${ }^{2}$ University of Warmia and Mazury, Department of Animal Nutrition and Feed Management, \\ Oczapowskiego 5,10-718 Olsztyn, Poland
}

KEY WORDS: endogenous urea, ${ }^{15} \mathrm{~N}$, dietary protein, milk, amino acids, dairy goats

Received: 21 February 2014

Revised: 14 July 2014

Accepted: 21 August 2014

${ }^{3}$ Corresponding author:

e-mail: j.p.michalski@op.pl

\begin{abstract}
The aim of the study was to estimate how much endogenous urea nitrogen (EUN) was incorporated into various amino acids of milk protein when goats were fed low (LP), medium (MP), or high protein (HP) diets in a $3 \times 3$ Latin-square design. Three Alpine goats of about $35 \mathrm{~kg}$ body weight fitted with a catheter into the jugular vein were fed isoenergetic diets containing $11 \%(\mathrm{LP}), 13 \%(\mathrm{MP})$, or $16 \%(\mathrm{HP})$ crude protein in dry matter. They were continuously infused with ${ }^{15} \mathrm{~N}$ urea into the jugular vein for 6 days. Daily milk yield was $1.58,1.49$ and $1.77 \mathrm{~g}$. Milk urea concentrations were 139, 342 and $451 \mathrm{mg} \cdot \mathrm{I}^{-1}$, whereas plasma urea was 178,356 and $667 \mathrm{mg} \cdot \mathrm{l}^{-1}$ in groups LP, MP and HP, respectively. Samples of milk protein were hydrolysed with $6 \mathrm{M} \mathrm{HCl}$, and then free amino acids were converted into butyl derivatives using $\mathrm{HCl}$ in butanol, followed by $\mathrm{N}$-acylation using trifluoroacetic acid anhydride. The amino acid derivatives were analysed using a gas chromatograph equipped with a mass detector. ${ }^{15} \mathrm{~N}$-excess after a six-day infusion of labelled urea was significantly higher $(P<0.05)$ in the vast majority of amino acids of milk protein from goats fed the LP diet in comparison with goats fed the HP diet. Therefore, the protein level of diets affects the incorporation of EUN into amino acids of milk protein. EUN was incorporated primarily into glutamic acid, methionine and arginine. At all levels of nitrogen in the diets, the incorporation of ${ }^{15} \mathrm{~N}$ into phenylalanine was very low.
\end{abstract}

\section{Introduction}

In ruminants, endogenous urea nitrogen (EUN) is formed in the liver and can be transferred to the rumen (Kowalczyk et al., 1975a,b; Harmeyer and Martens, 1980; Kennedy and Milligan, 1980), where it is then hydrolysed (Gibbons and McKarthy, 1957) and the resulting ammonia enters the ruminal ammonia pool (Bunting et al., 1989). It is utilized by rumen bacteria as an important source of nitrogen for bacterial protein synthesis (Virtanen, 1964). This EUN is incorporated in various proportions into different amino acids of bacterial protein; the proportions depend on the composition of the diet (Havassy et al., 1982; Michalski et al., 2013). These amino acids can then be incorporated into milk protein.

The metabolism of the mammary gland is very complex. Although there are numerous studies on amino acid and protein metabolism in the mamma- 
ry gland of the lactating ruminant (Bequette et al., 1998), little is known about the utilization of blood urea nitrogen during this period (Brun-Bellut, 1996; Al-Dehneh et al., 1997), especially on the influence of dietary protein level on incorporation of endogenous urea nitrogen into milk protein (Pfeffer et al., 2009; Michalski et al., 2012).

We were unable to find any studies on the incorporation of endogenous urea nitrogen into individual amino acids of ruminant milk. It is not known whether and to what extent the protein level in the diets affects the preference for and extent of incorporation of recycled nitrogen into individual amino acids of milk. The hypothesis of our study was that incorporation of endogenous urea nitrogen into various amino acids of milk depends on the dietary protein level. Therefore, the aim of the current study was to estimate the magnitude of incorporation of endogenous urea nitrogen into the individual amino acids of milk protein in goats fed diets containing low, medium, or high protein levels.

\section{Material and methods}

\section{Animals and nutrition}

The studies were conducted on three Alpine goats at 105 days of first lactation in a $3 \times 3$ Latinsquare design. The goats were 12 months old with a $35 \pm 2 \mathrm{~kg}$ body weight. The animals were housed and handled in accordance with protocols approved by the Local Animal Care and Use Committee. Animals fitted with a polyurethane catheter into the jugular vein $(16 \mathrm{G} \times 200 \mathrm{~mm})$ were housed in individual cages. They were fed $1200 \mathrm{~g}$ of grass hay and $1000 \mathrm{~g}$ of one of three isoenergetic concentrates containing a low (LP), medium (MP), or high (HP) level of protein, respectively. The crude protein concentration in the whole diet was $11 \%, 13 \%$ and $16 \%$ in dry matter (DM), respectively, and soyabean made up most of the protein source. Almost $65 \%$ of the soyabean protein is degradable in the rumen (NRC, 2001), so diets differed mainly in rumen-degradable protein as well as rumen-undegradable protein. The diet

Table 1. The nutrient content in feeds, $\%$ in DM

\begin{tabular}{lrrrr}
\hline \multirow{2}{*}{ Indices } & \multirow{2}{*}{ Hay } & \multicolumn{3}{c}{ Concentrate, protein level } \\
\cline { 3 - 5 } & & \multicolumn{1}{l}{ low } & medium & \multicolumn{1}{l}{ high } \\
\hline Dry matter & 91.53 & 89.21 & 89.68 & 89.68 \\
Crude protein & 11.27 & 11.07 & 15.05 & 21.60 \\
Ether extract & 2.15 & 0.95 & 1.65 & 2.21 \\
Crude fibre & 30.66 & 8.51 & 8.40 & 8.08 \\
NDF & 62.38 & 31.41 & 32.80 & 30.73 \\
Ash & 5.95 & 4.24 & 4.72 & 5.54 \\
ME, MJ $\cdot \mathrm{kg}^{-1}$ & 10.55 & 12.58 & 12.56 & 12.44 \\
\hline
\end{tabular}

containing the medium level of protein best met NRC norms (2007). Water was freely available. Concentrate composition was reported in detail in our previous paper (Michalski et al., 2013). The nutrient contents are given in Table 1.

\section{Experimental design, sampling and ${ }^{15} \mathrm{~N}$-urea infusion}

After a 15-day adaptation period, samples of milk, blood and feeds were collected for respective analysis. Blood samples from the jugular vein were collected twice a day at 08.00 and $14.00 \mathrm{~h}$ in heparinized tubes, placed on crushed ice and centrifuged at $1450 \mathrm{~g}$ for $15 \mathrm{~min}$ at $4^{\circ} \mathrm{C}$ for preparation of plasma. Collected samples were stored at $-20^{\circ} \mathrm{C}$ until analysis. Goats were milked twice a day at 06.00 and $18.00 \mathrm{~h}$; milk was weighed and pooled for $24 \mathrm{~h}$ periods. A total of 144 blood samples and 72 milk samples were collected.

Blood urea nitrogen was labelled with the stable isotope of nitrogen $\left({ }^{15} \mathrm{~N}\right)$ to estimate the efficiency of blood EUN utilization for synthesis of milk amino acids and estimation the losses of EUN as milk urea. From the second day of sample collection, for 6 days goats were administered ${ }^{15} \mathrm{~N}$-labelled urea (98 atom \% excess; VEB Berlin-Chemie, Germany); $1.6 \mathrm{~g} \cdot \mathrm{d}^{-1}{ }^{15} \mathrm{~N}$-urea were continuously infused into the jugular vein as described in detail in a previous paper (Michalski et al., 2013). The amount of administered ${ }^{15} \mathrm{~N}$-urea was chosen based on our previous studies (Michalski et al., 2012). Based on the detection capabilities, we found that the optimal amount was $\sim 5 \mathrm{mg}{ }^{15} \mathrm{~N} \cdot \mathrm{kg}^{-1}$ body weight per day.

\section{Analysis}

The nutrient content of feeds and refusals were determined according to AOAC procedures (1990). The nutrient composition of consumed feed was calculated by subtracting the nutrient content of the refusals from the nutrient content of the diet. Milk composition was estimated by near-infrared spectroscopy (MilkoScan FT120, Foss). The concentration of urea in milk samples was quantified using high-performance liquid chromatography with pre-column derivation (Czauderna and Kowalczyk, 2009). Milk protein was prepared by precipitation with $20 \%$ trichloroacetic acid (2:1, v/v) and centrifugation $\left(300 \mathrm{~g}\right.$ for $5 \mathrm{~min}$ at $\left.4^{\circ} \mathrm{C}\right)$. The resulting precipitate was washed with methanol and dried. The supernatant obtained during centrifugation was used to obtain the free amino acids of milk. For this purpose the supernatant was filtered $(30-\mathrm{SF}-45 \mathrm{~N}$; Chromacol) and vacuum solid-phase extraction (SPE) was carried out on the respective stationary 
phase (Strata-X-C 33u Polymeric Strong Cation $60 \mathrm{mg} \cdot 3 \mathrm{ml}^{-1}$; Phenomenex). The obtained eluent containing free amino acids was concentrated under a stream of argon.

The milk protein was hydrolysed in culture tubes, using $6 \mathrm{M} \mathrm{HCl}$ in water at $105^{\circ} \mathrm{C}$ for $22 \mathrm{~h}$, and the samples were dried with a rotary evaporator at $60^{\circ} \mathrm{C}$. Free amino acids were derivatized according to the procedure specified by Gehrke (2005) that was described in detail in a previous publication (Michalski et al., 2013). N-trifluoroacetyl n-butyl esters of amino acids were analysed using a gas chromatograph with a mass-selective detector using a capillary column $(30 \mathrm{~m} \times 0.25 \mathrm{~mm} \times 0.25 \mu \mathrm{m})$. The excess of the ${ }^{15} \mathrm{~N}$ isotope in individual amino acids was calculated by reading the intensity of individual ions with a mass detector. Glutamine and glutamic acid as well as asparagine and aspartic acid were determined together as $\mathrm{N}$-acylated butyl derivatives of glutamic and aspartic acids. ${ }^{15} \mathrm{~N}$ isotope enrichment analysis were performed on the samples collected pre-infusion and on day 6 of the infusion.

The data were statistically analysed using the non-parametric Mann-Whitney U test for comparing independent experimental groups. The Statistica v. 10 package (2010) was used (www.statsoft.pl).

\section{Results and discussion}

No significant differences in dry matter intake or in the percentage of crude fibre were found among the LP, MP and HP diets of goats (Table 2). The crude protein contents in the dry matter of feed intake differed statistically. Milk yield was correlated with dry matter intake $(r=0.982)$ and milk fat content increased with increasing levels of protein in the diets (Table 2). The level of protein in the diet did not affect the percentage of protein in milk. A positive correlation $(r=0.707)$ was observed between the

Table 2. Diet intake, nutrient composition of feed intake, milk yield, milk urea and plasma urea concentration. Mean values $\pm \mathrm{SD}^{1,2}$

\begin{tabular}{lcrr}
\hline \multirow{2}{*}{ Indices } & \multicolumn{4}{l}{ Protein level in diets } \\
\cline { 2 - 5 } & \multicolumn{1}{c}{ low } & \multicolumn{3}{l}{ medium } & \multicolumn{2}{l}{ high } \\
\hline Diet intake, $\mathrm{kg} \cdot \mathrm{DM} \cdot \mathrm{d}^{-1}$ & $1.66 \pm 0.20$ & $1.64 \pm 0.23$ & $1.78 \pm 0.13$ \\
Crude protein, \% DM & $11.49^{\mathrm{a}} \pm 0.41$ & $13.27^{\mathrm{b}} \pm 0.24$ & $17.18^{\mathrm{C}} \pm 0.42$ \\
$\mathrm{ME}, \mathrm{MJ} \cdot \mathrm{kg}{ }^{-1} \mathrm{DM}$ & $11.92 \pm 0.18$ & $11.78 \pm 0.02$ & $11.73 \pm 0.08$ \\
Milk yield, $\mathrm{kg} \cdot$ day $^{-1}$ & $1.58^{\mathrm{a}} \pm 0.18$ & $1.49^{\mathrm{Aa}} \pm 0.30$ & $1.77^{\mathrm{Bb}} \pm 0.23$ \\
Milk fat, \% & $2.72^{\mathrm{a}} \pm 0.28$ & $2.78^{\mathrm{ab}} \pm 0.50$ & $2.94^{\mathrm{b}} \pm 0.29$ \\
Milk protein, \% & $2.85 \pm 0.27$ & $2.82 \pm 0.61$ & $2.89 \pm 0.17$ \\
Milk urea, $\mathrm{mg} \cdot \mathrm{l}^{-1}$ & $138.9^{\mathrm{A}} \pm 41.9$ & $341.9^{\mathrm{Ba}} \pm 99.2$ & $451.3^{\mathrm{Bb}} \pm 156.1$ \\
Plasma urea, $\mathrm{mg} \cdot l^{-1}$ & $178^{\mathrm{A}} \pm 64$ & $356^{\mathrm{B}} \pm 161$ & $667^{\mathrm{C}} \pm 251$
\end{tabular}

${ }^{1}$ some of the data were presented in our previous paper (Michalski et al., 2012); ${ }^{2}$ mean values in rows having the different superscripts are significantly different at ${ }^{\mathrm{a}, \mathrm{b}} \mathrm{P}<0.05$ and ${ }^{\mathrm{A}, \mathrm{B}} \mathrm{P}<0.01$ levels, respectively protein content of the diet and urea in milk (Table 2), which is in agreement with other studies (Zhai et al., 2007). The concentration of urea in milk was lower than in plasma, which is consistent with the results of Wang et al. (2007) and Zhai et al. (2007). Plasma urea concentrations differed significantly between groups $(P<0.01)$, and increased together with the level of protein in the diets (Table 2). At the medium level of protein, urea in blood plasma was increased by $100 \%$, and at the high level, by $275 \%$.

The amino acid profile of milk protein (Figure 1) was similar to results published by other authors (Davis et al., 1994; Rutherfurd et al., 2006). This profile was similar in all levels of protein in the diet. We found a numerical increase in the concentration of the analysed amino acids in milk protein.

${ }^{15} \mathrm{~N}$-labelled nitrogen was present in all analysed amino acids of milk protein. The protein level in the diets affects EUN incorporation in individual amino acids of milk protein. In the case of seven amino acids, the effect was statistically significant $(P<0.05)$. For low-protein diets, high enrichment was observed in methionine, isoleucine, and glutamic acid (Table 3). In high-protein diets, the greatest enrichment was also observed in glutamic acid, and in arginine and leucine. The level of protein in the diet had the least impact on the enrichment of phenylalanine.

It is noteworthy that the content of ${ }^{15} \mathrm{~N}$ was high in milk urea and quite high in arginine, but much lower in proline. The amount of arginine excreted in milk proteins (protein outputs) is much smaller than the quantity extracted from the blood by the mammary gland (Bequette et al., 1998). This means that only part of the arginine is used in milk protein synthesis, and most of it is broken down in the mammary gland (Mezl and Knox, 1977), resulting in milk urea. Proline extracted by the mammary gland does not meet the needs of milk synthesis and

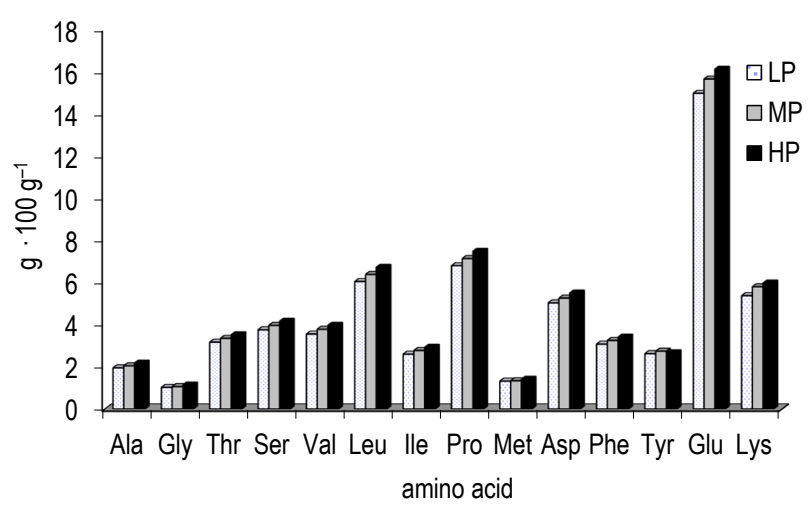

Figure 1. The mean concentrations of amino acids in milk protein, $g \cdot 100 \cdot g^{-1}$ 
Table $3 .{ }^{15} \mathrm{~N}$ (at \% excess) in milk urea and in individual amino acids of milk protein after infusion of ${ }^{15} \mathrm{~N}$ labeled urea. Mean values $\pm \mathrm{SD}(\mathrm{n}=9)$

\begin{tabular}{|c|c|c|c|}
\hline \multirow{2}{*}{ Indices } & \multicolumn{3}{|c|}{ Protein level in diets ${ }^{1}$} \\
\hline & low & medium & high \\
\hline Milk urea & $2.622 \pm 1.265$ & $3.077 \pm 0.837$ & $2.499 \pm 0.636$ \\
\hline Alanine (Ala) & $0.450^{\mathrm{a}} \pm 0.134$ & $0.408^{\mathrm{a}} \pm 0.079$ & $0.196^{b} \pm 0.088$ \\
\hline Glycine (Gly) & $0.490 \pm 0.383$ & $0.508 \pm 0.677$ & $0.234 \pm 0.229$ \\
\hline Threonine (Thr) & $0.400 \pm 0.178$ & $0.305 \pm 0.257$ & $0.185 \pm 0.062$ \\
\hline Serine (Ser) & $0.361 \pm 0.320$ & $0.182 \pm 0.173$ & $0.170 \pm 0.101$ \\
\hline Valine (Val) & $0.436^{a} \pm 0.114$ & $0.305^{\mathrm{ab}} \pm 0.128$ & $0.102^{b} \pm 0.113$ \\
\hline Leucine (Leu) & $0.544^{\mathrm{a}} \pm 0.173$ & $0.397^{a} \pm 0.111$ & $0.209^{b} \pm 0.016$ \\
\hline Isoleucine (lle) & $0.702^{\mathrm{a}} \pm 0.204$ & $0.442^{\mathrm{a}} \pm 0.212$ & $0.000^{b} \pm 0.195$ \\
\hline Proline (Pro) & $0.397 \pm 0.150$ & $0.294 \pm 0.142$ & $0.154 \pm 0.096$ \\
\hline Methionine (Met) & $0.895^{a} \pm 0.426$ & $0.796^{\mathrm{ab}} \pm 0.712$ & $0.103^{b} \pm 0.245$ \\
\hline Arginine (Arg)) & $0.905 \pm 0.321$ & $0.513 \pm 0.347$ & $0.386 \pm 0.498$ \\
\hline Aspartic acid (Asp) & $0.436 \pm 0.358$ & $0.329 \pm 0.275$ & $0.183 \pm 0.292$ \\
\hline Phenylalanine (Phe) & $0.216 \pm 0.099$ & $0.268 \pm 0.407$ & $0.154 \pm 0.218$ \\
\hline Glutamic acid (Glu) & $0.830^{\mathrm{a}} \pm 0.252$ & $0.878^{a} \pm 0.183$ & $0.324^{b} \pm 0.240$ \\
\hline Lysine (Lys) & $0.660^{a} \pm 0.236$ & $0.581^{\mathrm{a}} \pm 0.150$ & $0.126^{b} \pm 0.269$ \\
\hline
\end{tabular}

proline must be synthesized in the body (Mezl and Knox, 1977; Bequette et al., 2006).

The high content of the ${ }^{15} \mathrm{~N}$ isotope in milk urea and its low content in proline suggests that the ${ }^{15} \mathrm{~N}$ isotope from infused urea was incorporated mainly into the amidine group of bacterial arginine. Arginine was then utilized to produce proline in the mammary gland and the amidine group was used to form urea.

The relatively high ${ }^{15} \mathrm{~N}$ enrichment of methionine and lysine at the low- and medium-protein content of the diet can be explained by the fact that they are essential amino acids, often considered to be the limiting amino acids, particularly when heated soyabean make up most of the protein source. So most of these amino acids can originate directly from the amino acids of bacterial protein, produced from EUN. Similarly, the high content of EUN in the branched-chain amino acids, such as leucine and isoleucine, can be due to these amino acids being produced by ruminal bacteria using urea nitrogen, as ruminants are unable to synthesize them. Incorporation of ${ }^{15} \mathrm{~N}$ into these amino acids was low when the diet contained a high level of protein because the amount of dietary nitrogen was sufficient for microbial protein synthesis and only a small part of EUN was recycled to the rumen.

The high enrichment of glutamic acid can be explained by a large portion of arginine (which was highly enriched in the ${ }^{15} \mathrm{~N}$ isotope) being converted

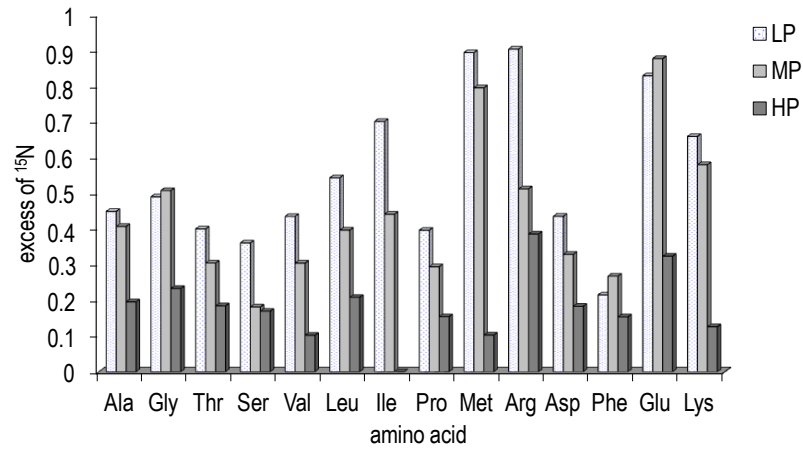

Figure 2. ${ }^{15} \mathrm{~N}$ (at \% excess) in individual amino acids of milk protein after infusion of ${ }^{15} \mathrm{~N}$ labeled urea

in the mammary gland to glutamic acid and glutamine (Mezl and Knox, 1977).

The high enrichment with ${ }^{15} \mathrm{~N}$ of glutamic acid, arginine, methionine, isoleucine, and lysine can be explained by the high incorporation of EUN in these amino acids of bacterial protein (Michalski et al., 2013).

The incorporation yield of endogenous urea nitrogen into amino acids of milk protein is reduced when the goat diet contains a high amount of protein.

The ${ }^{15} \mathrm{~N}$ content in free amino acids of milk was highly variable and there were no statistically significant differences (Table 4). There were, however, numerical differences between the enrichment in ${ }^{15} \mathrm{~N}$ of free amino acids of milk. The numerically higher content of ${ }^{15} \mathrm{~N}$ from infused urea in free arginine of milk in goats receiving the low-protein diet compared with goats receiving the high-protein diet $(P=0.0881)$ is noteworthy.

The present study confirms that EUN is used for synthesis of bacterial amino acids and that these amino acids are utilized in the mammary gland for synthesis of milk protein. The results of this study correspond to our previous data (Michalski et al., 2012) in which increasing the protein content in the diet reduced the efficiency with which endogenous urea nitrogen was incorporated into the amino acids of milk protein.

Table 4. ${ }^{15} \mathrm{~N}$ (at\% excess) in free amino acids of milk after infusion of ${ }^{15} \mathrm{~N}$ labeled urea. Mean values $\pm \mathrm{SD}(\mathrm{n}=9)$

\begin{tabular}{llll}
\hline \multirow{2}{*}{ Amino acids } & \multicolumn{3}{l}{ Protein level in diets } \\
\cline { 2 - 4 } & low & \multicolumn{3}{l}{ medium } \\
\hline Alanine (Ala) & $0.65 \pm 0.25$ & $0.77 \pm 0.68$ & $0.15 \pm 0.20$ \\
Glycine (Gly) & $1.20 \pm 1.27$ & $0.29 \pm 0.11$ & $0.50 \pm 0.23$ \\
Valine (Val) & $0.20 \pm 0.44$ & $0.24 \pm 0.13$ & $0.01 \pm 0.12$ \\
Leucine (Leu) & $0.61 \pm 0.01$ & $0.17 \pm 0.26$ & $0.00 \pm 0.35$ \\
Isoleucine (lle) & $0.85 \pm 0.89$ & $0.41 \pm 0.28$ & $0.29 \pm 0.08$ \\
Proline (Pro) & $0.42 \pm 0.23$ & $0.34 \pm 0.26$ & $0.14 \pm 0.06$ \\
Arginine (Arg) & $2.16 \pm 1.96$ & $0.22 \pm 1.56$ & $0.27 \pm 0.56$ \\
Lysine (Lys) & $0.50 \pm 0.31$ & $0.37 \pm 0.51$ & $0.00 \pm 0.36$ \\
\hline
\end{tabular}




\section{Conclusions}

It can be concluded that endogenous urea nitrogen is primarily built into glutamic acid, methionine and arginine, and the yield of incorporation of ${ }^{15} \mathrm{~N}$ into phenylalanine is very low, irrespective of the level of protein in the diets.

\section{Acknowledgements}

This work was supported by the National Science Centre, Project No. N N311 517740.

\section{References}

Al-Dehneh A., Huber J.T., Wadeley R., Theurer C.B., Pessarakli M., de Young D., 1997. Incorporated of recycled urea-N into ruminal bacteria flowing to the small intestine of dairy cows fed a high- grain or high-forage diet. Anim. Feed Sci. Tech. 68, 327-338

AOAC, 1990. Association of Official Analytical Chemists, Official Methods of Analysis. $15^{\text {th }}$ Edition. Arlington, VA

Bequette B.J., Backwell F.R., Crompton L.A., 1998. Current concepts of amino acid and protein metabolism in the mammary gland of the lactating ruminant. J. Dairy Sci. 81, 2540-2559

Bequette B.J., Sunny N.E., El-Kadi S.W., Owens S.L., 2006. Application of stable isotopes and mass isotopomer distribution analysis to the study of intermediary metabolism of nutrients. J. Anim. Sci. 84, Suppl., E50-E59

Brun-Bellut J., 1996. Urea recycling in the rumen of dairy goats: effects of physiological stage and composition of intake. Small Ruminants Res. 23, 83-90

Bunting L.D., Boling J.A., MacKown C.T., Davenport G.M., 1989. Effect of dietary protein level on nitrogen metabolism in the growing bovine: I Nitrogen recycling and intestinal protein supply in calves. J. Anim. Sci. 67, 820-826

Czauderna M., Kowalczyk J., 2009. Easy and accurate determination of urea in milk, blood plasma, urine and selected diets of mammals by high-performance liquid chromatography with photodiode array detection preceded by pre-column derivatization. Chem. Anal. (Warsaw) 54, 919-937

Davis T.A., Nguyen H.V., Garcia-Bravo R., Fiorotto M.L., Jackson E.M., Lewis D.S., Lee D.R., Reeds P.J.,1994. Amino acid composition of human milk is not unique. J. Nutr. 124, 1126-1132

Gehrke C.W., 2005. Quantitation of amino acids by gas-liquid chromatography. In: Ibolya Molnar-Perl (Editor). Quantitation of Amino Acids and Amines by Chromatography. Methods and Protocols. Elsevier, J. Chromatogr. Library 70, 39-97
Gibbons R.J., McKarthy R.D., 1957. Obligatory anaerobic ureahydrolyzing bacteria in the bovine rumen. Maryland Agric. Exp. Sta. Misc. Publ. 291, 12-16

Harmeyer J., Martens H., 1980. Aspects of urea metabolism in ruminants with reference to the goat. J. Dairy Sci. 63, 1707-1728

Havassy I., Kowalczyk J., Horsky K., Košta K., Otwinowska A., 1982. Incorporation of $15 \mathrm{~N}$ - urea into individual amino acids of rumen bacteria and blond plasma protein in sheep. Acta Physiol. Pol. 33, 415-419

Kennedy P.M., Milligan L.P., 1980. The degradation and utilization of endogenous urea in the gastrointestinal tract of ruminants: A review. Can. J. Anim. Sci. 60, 205-221

Kowalczyk J., Havassy I., Otwinowska A., Košta K., 1975a. Passage of intravenously administered $15 \mathrm{~N}$ urea into the digestive tract and its excretion in sheep. Acta Physiol. Pol. 26, 299-306

Kowalczyk J., Havassy I., Košta K., Otwinowska A., 1975b. Incorporation of intravenously administered $15 \mathrm{~N}$ labeled urea in to the bacterial protein in the sheep. Acta Physiol. Pol. 26, 307-312

Mezl V.A., Knox W.E., 1977. Metabolism of arginine in lactating rat mammary gland. Biochem. J. 166, 105-113

Michalski J.P., Kowalczyk J., Czauderna M., Litwin W., 2013. Incorporation of endogenous urea nitrogen into the amino acids in bacterial protein in rumen of goats fed diets with various protein levels. J. Anim. Feed Sci. 22, 311-315

Michalski J.P., Kowalczyk J., Voigt J., Hammon H.M., Czauderna M., Metges C.C., 2012. Efficiency of endogenous urea $15 \mathrm{~N}$ nitrogen incorporation into bacterial and milk protein of goats fed diets with three different protein levels. J. Anim. Feed Sci. 21, 599-612

NRC, 2001. Nutrient Requirements of Dairy Cattle. $7^{\text {th }}$ revised Edition. National Research Council. National Academic Press. Washington, DC

NRC, 2007. Nutrient requirements of small ruminants: sheep, goats, cervids, and New World camelids. National Research Council. National Academic Press. Washington, DC

Pfeffer E., Speckter H., Bornemann S., Holthausen A., Rodehutscord M., 2009. Kinetics of endogenous urea nitrogen in lactating goats and cows fed diets varying in their crude protein concentrations. Arch. Anim. Nutr. 63, 230-242

Rutherfurd S.M., Darragh A.J., Hendriks W.H., Prosser C.G., Lowry D.,2006. True ileal amino acid digestibility of goat and cow milk infant formulas. J. Dairy Sci. 89, 2408-2413

Virtanen A.I., 1964. Versuche über Milchproduktion ohne Protein unter ausschließlicher Verwendung von Harnstoff und Ammoniumstickstoff. Nachr. Gies. Hochsch.-Gesell. 33, 73-85

Wang C., Liu J.X., Yuan Z.P., Wu Y.M., Zhai S.W., Ye H.W., 2007. Effect of level of metabolizable protein on milk production and nitrogen utilization in lactating dairy cows. J. Dairy Sci. 90, 2960-2965

Zhai S.W., Liu J.X., Wu Y.M., Ye J., 2007. Predicting urinary nitrogen excretion by milk urea nitrogen in lactating Chinese Holstein cows. Anim. Sci. J. 78, 395-399 